\title{
The effect of the shape of gaps on microenvironmental conditions and seedling recruitment in Molinietum caeruleae meadows
}

\author{
Kinga Kostrakiewicz-Gierałt* \\ Department of Plant Ecology, Institute of Botany, Jagiellonian University, Lubicz 46, 31-512 Kraków, Poland
}

\begin{abstract}
Cessation of the management of semi-natural habitats such as grasslands and meadows contributes to secondary succession and encroachment of native and alien tall-growing perennials, large tussock grasses, shrubs, and trees. Thus, the formation of gaps in the plant canopy and litter, enabling seedling recruitment, appears to be a very effective method for the restoration of several plant communities. The main objective of the research was to assess the effect of the shape of openings on microenvironmental conditions and seedling recruitment in Molinietum caeruleae patches in various habitat conditions. In all study patches, circular and linear openings, comparable in area, were randomly created through the removal of plant canopy and litter layer. The circular gaps presented greater light availability and lower soil humidity than linear openings, while soil temperature within differently shaped openings was similar. Regardless of differences in microenvironmental conditions, the total number of seedlings in differently shaped gaps did not vary considerably. Three plant categories were found: (i) those recruited mostly in circular openings, (ii) those recruited mostly in linear gaps, (iii) those colonizing circular and linear gaps similarly. The colonizers of circular gaps represented various synecological groups (ruderal, grasslands and meadows, young tree communities) and diverse life forms (therophytes, hemicryptophytes, chamaephytes, phanerophytes), while the colonizers of linear gaps were meadow and grassland hemicryptophytes. The formation of linear openings contributes to increases in the abundance of meadow taxa, while the creation of circular openings may have a negative effect, contributing to the promotion of the secondary succession process.
\end{abstract}

Keywords: colonization; ground temperature; light availability; soil moisture; species richness; seedling abundance

\section{Introduction}

Cessation of the management of semi-natural habitats contributes to secondary succession and encroachment of native and alien tall-growing perennials, large tussock grasses, shrubs and trees [1-4]. This phenomenon is accompanied by greater litter accumulation as well as modification of soil properties, especially moisture and fertility. Secondary succession frequently leads to the fragmentation of communities and isolation of populations [5-7]. Small and isolated populations may suffer from a low level of genetic diversity and a high risk of individual mortality, frequently resulting in their extinction [8-11]. On the other hand, Czarnecka and Denisow [12] argued that genetic variability of small populations might be improved by long-distance moving pollinators.

In effect, secondary succession contributes to a decrease in plant species richness and to the loss of biodiversity within a community. Hitherto, this scenario has been repeatedly

\footnotetext{
* Email: kingakostrakiewicz@tlen.pl
}

Handling Editor: Elżbieta Weryszko-Chmielewska observed over a wide range of habitats [13]. Nowadays, Molinietum caeruleae meadows [14] are among the world's most threatened habitats; their combined area has diminished gradually over recent decades throughout Europe [15-18]. As a result, they have been designated for conservation by international conventions $[19,20]$ and included in the Natura 2000 network [21].

Meanwhile, numerous authors have documented that the formation of gaps in plant canopy and litter, enabling seedling recruitment, appears to be a very effective method for the restoration of Molinietum caeruleae meadows. To date, the majority of these authors [22-24] have studied the spontaneous colonization process in gaps created as a result of diverse treatments. They found that the greatest species richness and density of mature individuals and their seedlings were observed in openings left after clipping and removal of the aboveground parts of plants and the litter layer. Janeček \& Lepš [25] also showed the negative impact of litter, leaf cover and cover of basal internodes of Molinia caerulea on seedling recruitment. The investigations of Fibich et al. [26] documented that gaps are colonized predominantly from seeds. Other studies [27-30] documented that the number of species and seedlings occurring in gaps 
diminishes across the succession gradient from patches dominated by small meadow taxa, through those dominated by large tussock grasses, to those overgrown by shrubs and trees. The influence of the life history traits of clonal plants on the colonization of gaps left after weak, medium and strong disturbances was investigated by KostrakiewiczGierałt $[28,29]$, who also observed $[28,30]$ the effect of the life history traits of clonal plants on recruitment rates in gaps of different sizes as well as the role of seed weight in the colonization of small, intermediate and large openings [27]. Observations showed that, regardless of opening size, taxa characterized by medium seed mass are the most common in the seedling pool.

In spite of the growing interest in the processes of seedling recruitment in Molinietum caeruleae meadows, this issue remains insufficiently explored. So far, the effect of the shape of openings on microhabitat conditions and seedling recruitment is insufficiently understood. Especially interesting is the comparison of round vs. narrow openings in terms of light availability, soil moisture and temperature, as well as number of taxa and seedlings.

To address the present lack of knowledge, I studied the effects of circular and linear shape of openings on: $(i)$ microenvironmental conditions, (ii) numbers of species and their seedlings, and (iii) recruitment rates of particular taxa in patches dominated by small meadow taxa, by large tussock grasses, and overgrown by shrubs.

I hypothesized that:

(i) microsite conditions in differently shaped gaps are similar only in patches dominated by small meadow species, while in other patches they differ significantly. This hypothesis was based on the prediction that shading created by plants surrounding the gaps reduces light and temperature at ground level and increases soil moisture in the gaps. The effect of shading is considerably greater in narrow linear openings than in circular gaps, and increases in proportion to the dimensions of neighboring plants;

(ii) in all patches, a much greater number of species and seedlings occur in circular than in linear openings, because the former are recolonized more slowly by the clonal ingrowth of neighboring plants. In effect, they remain suitable sites for seedling recruitment much longer than narrow linear gaps;

(iii) the majority of taxa are circular gap colonizers. This assumption is linked with hypothesis 2 and assumes that the greatest number of taxa appears most abundantly in circular gaps, while species colonizing predominantly linear openings or linear and circular gaps to the same extent are rather rare.

\section{Material and methods}

\section{Study area}

The studies were carried out in the Kostrze district on the western border of Kraków south of the Vistula River (southern Poland). The research area is situated at ca. $210 \mathrm{~m}$ a.s.l., on the low flood terrace of the Vistula. Peaty or clayand silt-laden soils with fluctuating water tables are covered by Molinietum caeruleae patches [31]. The abandonment of traditional land use for at least the past dozen years has favored the encroachment of vegetation from the alliances Phragmition or Magnocaricion, leading to the fragmentation of meadows [32,33]. The meadows are surrounded by diverse vegetation types, including deciduous forests covering the slopes of the Vistula valley, calcareous grasslands occurring on limestone and chalk hill slopes, and ruderal communities appearing near buildings and along the edges of roads.

\section{Field trial}

The studies were carried out in a study area consisting of three adjacent abandoned patches of Molinietum caeruleae sensu Matuszkiewicz [34] characterized by the presence of the following taxa: Betonica officinalis L., Dianthus superbus L., Gentiana pneumonanthe L., Gladiolus imbricatus L., Iris sibirica L., Molinia caerulea (L.) Moench., Potentilla erecta (L.) Raeusch., Sanguisorba officinalis L., Selinum carvifolia (L.) L., and Succisa pratensis Moench. The studied patches differed as to dominant species. The Jacquard index between patch I and II reached 0.50; between patch I and III, 0.52 ; and between patch II and III, 0.54 . These high values indicate the significant floristic similarity of the studied patches. Patch I (5001'55.7" N; 1952'03.1" E), abandoned for ca. 20 years, was dominated by meadow species creating delicate erect (up to $30 \mathrm{~cm}$ ) or procumbent stems. Patch II $\left(50^{\circ} 01^{\prime} 55.2^{\prime \prime} \mathrm{N} ; 1^{\circ} 52^{\prime} 05.5^{\prime \prime} \mathrm{E}\right)$, not used for ca. 35 years, by large tussock grasses. Patch III ( $\left.50^{\circ} 01^{\prime} 55.6^{\prime \prime} \mathrm{N} ; 19^{\circ} 52^{\prime} 04.4^{\prime \prime} \mathrm{E}\right)$, unmanaged for at least 45 years, was overgrown by willow shrubs and bordered by trees. In July 2012, an evaluation of plant height from soil surface to the top flower $(n=30$, randomly chosen stems) was performed using a folding tape measure. Habitat conditions in the experimental patches are described in Tab. 1.

In each patch, 15 narrow linear openings, each with an area of $705.0 \mathrm{~cm}^{2}(47 \times 15 \mathrm{~cm})$, and 15 circular gaps covering $706.5 \mathrm{~cm}^{2}$ (radius $15 \mathrm{~cm}$ ) were created once, at the beginning of the experiment, on April 15, 2012. The gaps were created randomly as a result of clipping of all aboveground parts of plants at the soil level and removing them along with the litter layer. The underground organs of plants were not dug up. This treatment, considered optimal for seedling recruitment [27], was performed once, at the beginning of the investigations. The ramets of adjacent plants encroaching on the gap area during the growing season were not removed. The gaps were separated from each other by belts of untouched vegetation at least $3.0 \mathrm{~m}$ wide and were located ca. $2.0 \mathrm{~m}$ from the borders of the patches (Fig. 1).

Habitat conditions in the central part of each opening were monitored once a week from April 19 until November 30, 2012. All measurements were taken between 10.00 and 12.00 a.m. The light intensity at the soil level was examined with a Voltcraft MS-1300 digital light meter (accuracy $\pm 5 \%$ +10 digits; measuring range 0.01-50 000 lx). Humidity at ground level was measured using an OMEGA HSM50 handheld digital soil moisture sensor (accuracy $\pm 5 \%+5$ digits; measuring range 0 to $50 \%$ moisture content of soil). Soil temperature at a depth of $5 \mathrm{~cm}$ was measured using a Hanna electronic temperature sensor (accuracy $\pm 0.1^{\circ} \mathrm{C}$; measuring range $-10^{\circ} \mathrm{C}$ to $+60^{\circ} \mathrm{C}$ ). 
Tab. 1 The site conditions in patches of Molinietum caeruleae dominated by small meadow species (patch I), with large tussock grasses and macroforbs (patch II) as well as overgrown by willow shrubs and bordered by trees (patch III) in the year 2012.

\begin{tabular}{lccc}
\hline \multicolumn{1}{c}{ Patch: } & I & II & III \\
\hline Patch area $\left(\mathrm{m}^{2}\right)$ & 1700 & 1900 & 1600 \\
Number of species in patch & 56 & 47 & 39 \\
$\begin{array}{l}\text { Dominants (species, with } \\
\text { cover }>20 \%)\end{array}$ & $\begin{array}{l}\text { Lathyrus pratensis, Lotus } \\
\text { corniculatus }\end{array}$ & $\begin{array}{l}\text { Molinia caerulea, } \\
\text { Deschampsia caespitosa, } \\
\text { Lysimachia vulgaris, }\end{array}$ & $\begin{array}{l}\text { Salix repens ssp. } \\
\text { rosmarinifolia }\end{array}$ \\
$\begin{array}{l}\text { Subdominants (species, with } \\
\text { cover 5-20\%) }\end{array}$ & $\begin{array}{l}\text { Lychnis flos-cuculi, Succisa } \\
\text { pratensis }\end{array}$ & $\begin{array}{l}\text { Serratula tinctoria, } \\
\text { Polygonum bistorta }\end{array}$ & $\begin{array}{l}\text { Betula pendula, Populus } \\
\text { tremula }\end{array}$ \\
$\begin{array}{l}\text { Mean vascular plant height } \\
\text { (cm) }\end{array}$ & 44.9 & 88.6 & 114.2 \\
\hline
\end{tabular}

The value of statistical significance of differences (the H Kruskal-Wallis test, $d f=2$ ) among patches in vascular plant height was $39.39(P<0.001)$.

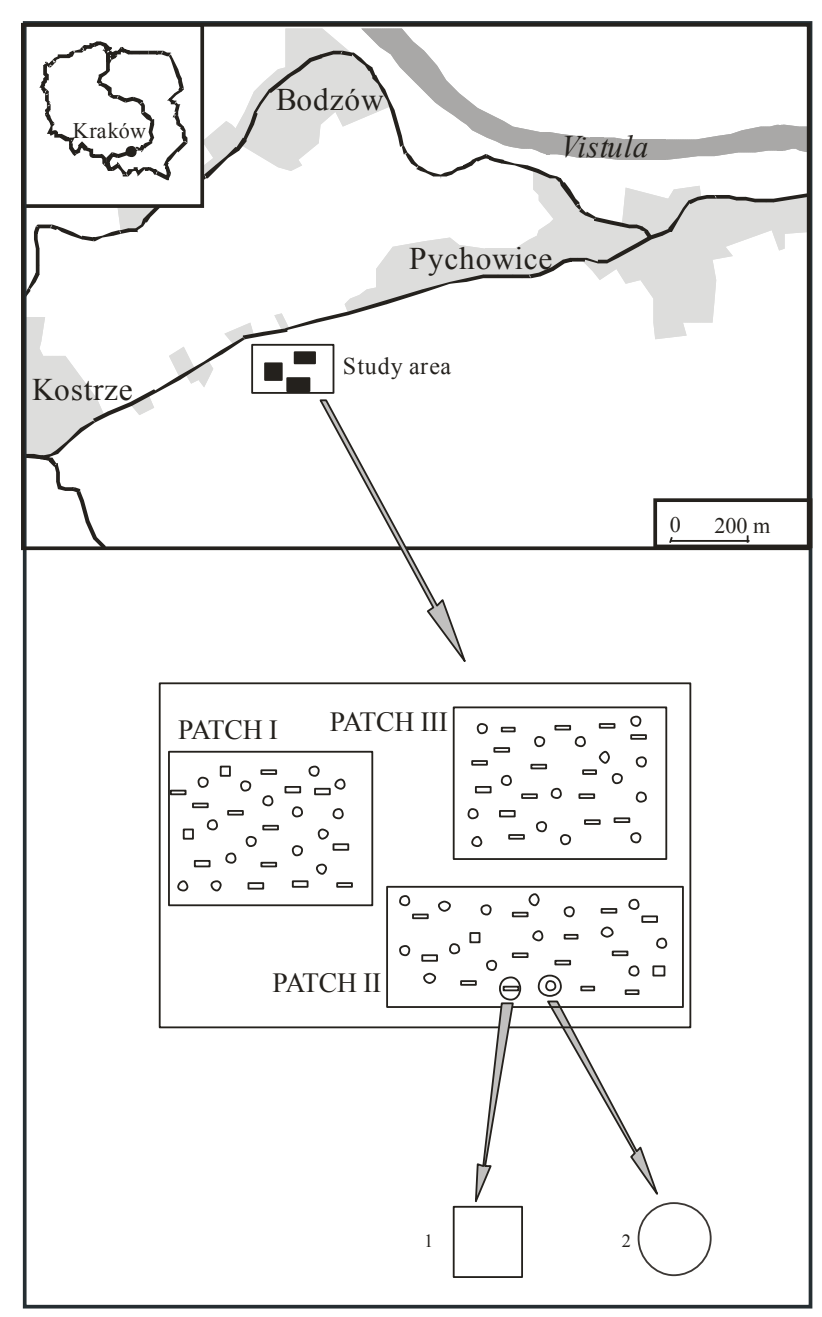

Fig. 1 The locality of patches of Molinietum caeruleae dominated by small meadow species (PATCH I), with large tussock grasses and macroforbs (PATCH II) as well as overgrown by willows prevailing, and bordered by trees (PATCH III), and the experimental design: 1 - linear gaps; 2 - circular gaps.
The process of gap colonization by generative offspring was monitored twice a week from April 19 until November 30, 2012. All recruits were removed and examined according to guides for seedling determination $[35,36]$ with the support of the author's own comparative collection. The nomenclature of taxa follows Mirek et al. [37]. Genets of rare and protected plants were marked with plastic rings and sticks.

\section{Data analysis}

All statistical analyses were computed using STATISTICA software (StatSoft, version 10). Analysis of data on microsite conditions was based on the Student's $t$-test (comparison between means), which was used to establish whether there were significant differences in:

(i) light intensity at the soil surface in linear and circular gaps in every study patch;

(ii) ground moisture in linear and circular gaps in every study patch;

(iii) soil temperature in linear and circular gaps in every study patch.

The Mann-Whitney U test was also used to establish if there were significant differences in:

(i) the total number of taxa/seedlings appearing in differently shaped gaps in every study patch;

(ii) the abundance of seedlings of particular taxa appearing in differently shaped gaps in every patch.

Subsequently, on the basis of the statistical analysis, all taxa appearing in the seedling pool were classified into the following groups of species:

(i) species which recruit mostly in circular gaps (when in all patches the number of seedlings in circular gaps was greater than in linear openings and when in at least one patch the difference was statistically significant); 
(ii) species which recruit mostly in linear gaps (when the number of seedlings in linear gaps was greater than in circular openings and when in at least one patch the difference was statistically significant);

(iii) other species (when the number of seedlings in linear gaps was insignificantly greater in all patches; when the number of seedlings in circular gaps was insignificantly greater in all patches; or when the number of seedlings was insignificantly greater in linear or in circular gaps depending on the patch).

\section{Results}

In all patches, light intensity was significantly higher in circular gaps than in linear openings. Ground moisture exhibited an inverse trend, while soil temperature in circular and linear openings did not vary remarkably (Tab. 2). In all patches, the mean number of species recorded in gaps with different shapes was similar. Also, the average number of seedlings noted in differently shaped gaps was rather similar (Tab. 3). Altogether, 65 taxa were found in the seedling pool: 15 taxa preferring circular openings (e.g. Solidago canadensis,
Filipendula ulmaria, Cirsium arvense, Tussilago farfara), 9 species recruiting chiefly in linear gaps (e.g. Sanguisorba officinalis, Succisa pratensis, Geranium pratense and Betonica officinalis), and 41 taxa classified as other species (e.g. Cirsium rivulare, Lotus corniculatus, Polygonum bistorta and Trifolium pratense), which showed no significant differences in recruitment rates between differently shaped gaps (Tab. 4 and Tab. 5).

\section{Discussion}

\section{Microenvironmental conditions in differently shaped gaps}

The obtained results partially confirm the hypothesis made at the beginning of the investigations and demonstrate the diverse microenvironmental conditions in circular and linear gaps in all the study sites. The diverse habitat conditions may be associated with various patterns of the revegetation process in differently shaped openings. Round gaps are colonized slowly through clonal ingrowth of the surrounding plants, since a circle has a minimal perimeterto-area ratio and a maximal proportion of surface distance from any edge [38]. Consequently, circles remain "open"

Tab. 2 The mean $( \pm S D)$ light intensity level, soil moisture and soil temperature in linear and circular shaped gaps in patches of Molinietum caeruleae dominated by small meadow species (patch I), with large tussock grasses and macroforbs (patch II), as well as overgrown by willow shrubs and bordered by trees (patch III) in the year 2012.

\begin{tabular}{lllll}
\hline Environmental & & & & Statistical \\
parameter & Patch & Circular gaps & Linear gaps & $\begin{array}{l}\text { Significance level (the } \\
\text { Student } \boldsymbol{t} \text {-test; } \boldsymbol{P})\end{array}$ \\
\hline Light intensity & I & $47291( \pm 10273) ; N=450$ & $43957( \pm 8243) ; N=450$ & $33.3(P<0.001)$ \\
& II & $41983( \pm 8432) ; N=450$ & $39291( \pm 9534) ; N=450$ & $23.2(P<0.001)$ \\
Soil moisture & III & $39426( \pm 7567) ; N=450$ & $36165( \pm 11432) ; N=450$ & $26.6(P<0.001)$ \\
& I & $19.4( \pm 4.9) ; N=450$ & $22.9( \pm 7.4) ; N=450$ & $-9.5(P<0.001)$ \\
Soil temperature & II & $30.1( \pm 9.7) ; N=450$ & $31.9( \pm 8.4) ; N=450$ & $-4.9(P<0.001)$ \\
& III & $37.6( \pm 11.6) ; N=450$ & $39.2( \pm 10.1) ; N=450$ & $-2.8(P<0.001)$ \\
& II & $12.7( \pm 3.2) ; N=450$ & $12.6( \pm 2.9) ; N=450$ & $0.1(P=0.85)$ \\
& III & $11.8( \pm 4.1) ; N=450$ & $11.7( \pm 6.3) ; N=450$ & $0.2(P=0.78)$ \\
& $10.9( \pm 5.6) ; N=450$ & $10.8( \pm 6.3) ; N=450$ & $0.2(P=0.74)$
\end{tabular}

Tab. 3 The average number of species $( \pm S D)$ and seedlings $( \pm S D)$ occurring in linear and circular gaps in patches of Molinietum caeruleae dominated by small meadow species (patch I), with large tussock grasses and macroforbs (patch II) as well as overgrown by willow shrubs and bordered by trees (patch III) in the year 2012.

\begin{tabular}{llccc}
\hline \multicolumn{1}{c}{ Patch } & Linear gaps & Circular gaps & $\begin{array}{l}\text { Statistical significance } \\
\text { level (the Mann- } \\
\text { Whitney U test; } \boldsymbol{P})\end{array}$ \\
\hline Species & I & $24.4( \pm 5.2)$ & $26.5( \pm 4.2)$ & $73.5(P=0.11)$ \\
& II & $20.4( \pm 3.6)$ & $22.2( \pm 4.3)$ & $101.0(P=0.64)$ \\
& III & $16.7( \pm 3.8)$ & $16.5( \pm 2.9)$ & $104.0(P=0.74)$ \\
& Seedlings & $41.5( \pm 19.3)$ & $42.6( \pm 16.2)$ & $75.0(P=0.12)$ \\
& I & $32.3( \pm 15.8)$ & $31.9( \pm 30.6)$ & $93.5(P=0.44)$ \\
& II & $29.1( \pm 25.9)$ & $27.2( \pm 8.5)$ & $103.5(P=0.70)$ \\
\hline
\end{tabular}


Tab. 4 The mean number of seedlings observed in linear (LI) and circular (CI) gaps in patches of Molinietum caeruleae dominated by small meadow species (patch I), with large tussock grasses and macroforbs (patch II) as well as overgrown by willow shrubs and bordered by trees (patch III) in the year 2012 .

\begin{tabular}{|c|c|c|c|c|c|c|c|}
\hline \multirow{2}{*}{$\begin{array}{l}\text { The group } \\
\text { of species }\end{array}$} & \multirow[b]{2}{*}{ Species } & \multicolumn{2}{|c|}{ Patch I } & \multicolumn{2}{|c|}{ Patch II } & \multicolumn{2}{|c|}{ Patch III } \\
\hline & & LI & CI & LI & CI & LI & $\mathrm{CI}$ \\
\hline \multirow[t]{15}{*}{ A } & Solidago canadensis & 6.9 & 9.8 & 4.0 & 7.2 & 3.1 & 5.1 \\
\hline & Filipendula ulmaria & 5.8 & 8.3 & 3.8 & 7.1 & 3.1 & 5.9 \\
\hline & Cirsium arvense & 4.1 & 7.3 & 3.2 & 6.2 & 2.7 & 5.1 \\
\hline & Tussilago farfara & 0.9 & 1.8 & 0.7 & 1.6 & 0.1 & 0.9 \\
\hline & Achillea millefolium & 6.3 & 8.8 & 4.1 & 4.5 & 2.5 & 5.1 \\
\hline & Chenopodium album & 1.9 & 4.7 & 0.6 & 2.6 & 1.5 & 1.7 \\
\hline & Galium boreale & 2.5 & 6.8 & 3.9 & 6.4 & 2.9 & 5.2 \\
\hline & Lysimachia vulgaris & 2.8 & 6.1 & 3.5 & 4.7 & 2.6 & 3.9 \\
\hline & Iris sibirica & 2.4 & 5.8 & 1.4 & 2.5 & 1.8 & 3.1 \\
\hline & Geum rivale & 1.5 & 4.6 & 1.2 & 2.8 & 0.9 & 1.2 \\
\hline & Betula pendula & 1.2 & 3.1 & 2.2 & 4.3 & 1.7 & 4.8 \\
\hline & Leucanthemum vulgare & 5.8 & 9.2 & - & - & 0.3 & 2.9 \\
\hline & Galinsoga sp. & 1.1 & 3.6 & 0.6 & 1.8 & - & - \\
\hline & Sonchus arvensis & 1.7 & 3.2 & 0.8 & 1.9 & - & - \\
\hline & Erigeron sp. & 1.6 & 3.8 & 0.9 & 1.2 & - & - \\
\hline \multirow[t]{9}{*}{ B } & Sanguisorba officinalis & 10.2 & 7.3 & 6.1 & 4.0 & 4.6 & 2.8 \\
\hline & Succisa pratensis & 7.4 & 4.3 & 6.6 & 3.1 & 3.6 & 1.7 \\
\hline & Geranium pratense & 4.8 & 1.7 & 4.3 & 2.4 & 2.5 & 2.4 \\
\hline & Betonica officinalis & 10.3 & 6.1 & 7.9 & 5.6 & 3.7 & 3.4 \\
\hline & Potentilla erecta & 7.7 & 4.1 & 3.9 & 3.5 & 2.3 & 2.0 \\
\hline & Serratula tinctoria & 5.9 & 4.1 & 6.2 & 3.1 & 4.5 & 4.1 \\
\hline & Lychnis flos-cuculi & 3.2 & 1.6 & 2.4 & 1.3 & - & - \\
\hline & Selinum carvifolia & 4.8 & 2.2 & 2.7 & 1.4 & - & - \\
\hline & Filipendula vulgaris & 4.3 & 1.9 & - & - & - & - \\
\hline \multirow[t]{32}{*}{$\mathrm{C}$} & Caltha palustris & 1.5 & 1.3 & 1.7 & 1.4 & 2.1 & 1.6 \\
\hline & Cardamine pratensis & - & - & - & - & 0.3 & 0.7 \\
\hline & Carex sp. & 0.0 & 0.3 & 0.3 & 0.5 & 0.4 & 0.6 \\
\hline & Centaurea jacea & 2.9 & 2.3 & 2.2 & 1.9 & - & - \\
\hline & Cirsium rivulare & 5.2 & 4.7 & 3.1 & 3.1 & 3.1 & 3.3 \\
\hline & Crepis paludosa & - & - & 0.7 & 0.9 & 0.7 & 0.5 \\
\hline & Daucus carota & 1.9 & 1.9 & 1.2 & 1.8 & 2.8 & 3.1 \\
\hline & Dianthus superbus & 1.5 & 1.2 & 1.3 & 0.9 & 0.8 & 0.6 \\
\hline & Epilobium sp. & 2.1 & 2.7 & 1.9 & 1.7 & 2.9 & 2.7 \\
\hline & Juncus sp. & 0.9 & 1.1 & 1.1 & 0.9 & 1.0 & 1.2 \\
\hline & Lathyrus pratensis & 0.7 & 1.5 & 0.5 & 0.3 & 0.3 & 0.1 \\
\hline & Lotus corniculatus & 4.0 & 3.5 & 3.8 & 4.3 & 3.2 & 3.1 \\
\hline & Lysimachia nummularia & 4.7 & 4.4 & 5.1 & 4.5 & - & - \\
\hline & Lythrum salicaria & 0.0 & 0.3 & 0.0 & 0.3 & 2.2 & 2.0 \\
\hline & Mentha longifolia & 3.3 & 3.3 & 3.5 & 3.3 & 1.6 & 1.5 \\
\hline & Myosotis palustris & 0.6 & 0.8 & 0.2 & 0.4 & 0.4 & 0.3 \\
\hline & Plantago lanceolata & 1.9 & 1.8 & 0.1 & 0.3 & 0.7 & 0.2 \\
\hline & Poaceae & 3.7 & 3.9 & 2.2 & 2.0 & 1.3 & 1.6 \\
\hline & Polygonum aviculare & 0.0 & 0.1 & - & - & 0.6 & 0.8 \\
\hline & Polygonum bistorta & 6.1 & 5.6 & 4.7 & 4.6 & 3.7 & 3.6 \\
\hline & Populus sp. & 0.0 & 0.1 & - & - & 1.5 & 1.4 \\
\hline & Prunella vulgaris & 1.2 & 1.5 & 0.9 & 1.1 & - & - \\
\hline & Ranunculus acer & 1.1 & 1.1 & 0.6 & 0.7 & - & - \\
\hline & Rumex acetosa & 0.3 & 0.5 & 0.8 & 1.1 & 1.0 & 0.9 \\
\hline & Salix sp. & 0.0 & 0.8 & 0.5 & 0.4 & 1.3 & 1.1 \\
\hline & Taraxacum sp. & 0.8 & 0.7 & 0.4 & 0.4 & - & - \\
\hline & Trifolium pretense & 1.2 & 1.1 & 0.8 & 0.5 & - & - \\
\hline & Urtica dioica & 0.5 & 0.5 & 0.3 & 0.3 & 0.3 & 0.1 \\
\hline & Valeriana officinalis & 1.5 & 1.5 & 2.0 & 1.8 & 3.1 & 2.7 \\
\hline & Veronica sp. & 0.7 & 0.5 & - & - & - & - \\
\hline & Vicia cracca & 1.9 & 1.6 & - & - & - & - \\
\hline & Viola sp. & 0.9 & 0.6 & 0.4 & 0.3 & 0.4 & 0.2 \\
\hline
\end{tabular}

The group of species: A - species recruit mostly in circular gaps; B - species recruit mostly in linear gaps; $\mathrm{C}$ - species recruit equally in linear and circular gaps. 
Tab. 5 The statistical significance level of differences among number of seedlings observed in linear and circular gaps in patches of Molinietum caeruleae dominated by small meadow species (patch I), with large tussock grasses and macroforbs (patch II) as well as overgrown by willow shrubs and bordered by trees (patch III) in the year 2012.

\begin{tabular}{|c|c|c|c|c|c|c|c|}
\hline \multirow[b]{2}{*}{$\begin{array}{l}\text { The group } \\
\text { of species }\end{array}$} & \multirow[b]{2}{*}{ Species } & \multicolumn{2}{|c|}{ Patch I } & \multicolumn{2}{|c|}{ Patch II } & \multicolumn{2}{|c|}{ Patch III } \\
\hline & & $\begin{array}{c}\text { The Mann- } \\
\text { Whitney U test } \\
\text { value }\end{array}$ & $P$ value & $\begin{array}{c}\text { The Mann- } \\
\text { Whitney } U \text { test } \\
\text { value }\end{array}$ & $P$ value & $\begin{array}{c}\text { The Mann- } \\
\text { Whitney U test } \\
\text { value }\end{array}$ & $P$ value \\
\hline \multirow[t]{15}{*}{ A } & Solidago canadensis & 64.0 & 0.04 & 48.5 & 0.008 & 66.0 & 0.04 \\
\hline & Filipendula ulmaria & 63.0 & 0.04 & 53.5 & 0.01 & 48.5 & 0.008 \\
\hline & Cirsium arvense & 42.5 & 0.003 & 42.5 & 0.003 & 64.0 & 0.04 \\
\hline & Tussilago farfara & 38.0 & 0.002 & 52.0 & 0.01 & 57.0 & 0.02 \\
\hline & Achillea millefolium & 32.0 & 0.0009 & 94.5 & 0.45 & 46.5 & 0.006 \\
\hline & Chenopodium album & 63.0 & 0.04 & 57.0 & 0.02 & 100.0 & 0.61 \\
\hline & Galium boreale & 28.0 & 0.0004 & 63.5 & 0.04 & 67.0 & 0.06 \\
\hline & Lysimachia vulgaris & 38.0 & 0.002 & 80.0 & 0.22 & 102.0 & 0.67 \\
\hline & Iris sibirica & 57.0 & 0.02 & 78.5 & 0.16 & 73.0 & 0.10 \\
\hline & Geum rivale & 33.0 & 0.001 & 77.0 & 0.14 & 75.5 & 0.13 \\
\hline & Betula pendula & 53.5 & 0.01 & 80.0 & 0.18 & 59.0 & 0.02 \\
\hline & Leucanthemum vulgare & 39.5 & 0.002 & - & - & 11.0 & 0.0002 \\
\hline & Galinsoga sp. & 96.5 & 0.06 & 43.0 & 0.004 & - & - \\
\hline & Sonchus arvensis & 47.0 & 0.007 & 47.5 & 0.007 & - & - \\
\hline & Erigeron sp. & 51.5 & 0.01 & 107.0 & 0.83 & - & - \\
\hline \multirow[t]{9}{*}{$\mathrm{B}$} & Sanguisorba officinalis & 64.5 & 0.04 & 60.0 & 0.03 & 54.0 & 0.01 \\
\hline & Succisa pratensis & 63.0 & 0.04 & 37.5 & 0.002 & 46.0 & 0.006 \\
\hline & Geranium pratense & 43.0 & 0.004 & 59.0 & 0.02 & 104.0 & 0.74 \\
\hline & Betonica officinalis & 6.0 & 0.00001 & 80.0 & 0.18 & 101.0 & 0.64 \\
\hline & Potentilla erecta & 29.0 & 0.0006 & 112.0 & 0.95 & 99.0 & 0.58 \\
\hline & Serratula tinctoria & 101.5 & 0.66 & 52.5 & 0.01 & 106.5 & 0.81 \\
\hline & Lychnis flos-cuculi & 50.0 & 0.01 & 106.0 & 0.80 & - & - \\
\hline & Selinum carvifolia & 58.0 & 0.02 & 71.0 & 0.08 & - & - \\
\hline & Filipendula vulgaris & 63.5 & 0.004 & 112.5 & - & - & - \\
\hline \multirow[t]{32}{*}{$\mathrm{C}$} & Caltha palustris & 82.0 & 0.21 & 87.0 & 0.29 & 96.5 & 0.50 \\
\hline & Cardamine pratensis & - & - & - & - & 90.0 & 0.36 \\
\hline & Carex sp. & 105.0 & 0.77 & 99.5 & 0.60 & 105.0 & 0.77 \\
\hline & Centaurea jacea & 107.5 & 0.85 & 110.0 & 0.93 & - & - \\
\hline & Cirsium rivulare & 89.5 & 0.35 & 105.0 & 0.78 & 108.0 & 0.86 \\
\hline & Crepis paludosa & - & - & 107.5 & 0.85 & 104.5 & 0.75 \\
\hline & Daucus carota & 102.0 & 0.67 & 102.5 & 0.69 & 82.5 & 0.22 \\
\hline & Dianthus superbus & 111.0 & 0.96 & 107.0 & 0.83 & 100.5 & 0.63 \\
\hline & Epilobium sp. & 100.5 & 0.63 & 109.5 & 0.91 & 112.0 & 0.99 \\
\hline & Juncus sp. & 100.0 & 0.61 & 109.0 & 0.90 & 111.0 & 0.96 \\
\hline & Lathyrus pratensis & 110.5 & 0.17 & 99.0 & 0.58 & 96.5 & 0.52 \\
\hline & Lotus corniculatus & 92.5 & 0.41 & 99.0 & 0.57 & 102.0 & 0.67 \\
\hline & Lysimachia nummularia & 97.5 & 0.54 & 101.0 & 0.64 & - & - \\
\hline & Lythrum salicaria & 105.0 & 0.77 & 105.0 & 0.77 & 104.0 & 0.74 \\
\hline & Mentha longifolia & 83.5 & 0.23 & 100.0 & 0.61 & 111.0 & 0.96 \\
\hline & Myosotis palustris & 103.5 & 0.72 & 105.0 & 0.76 & 111.5 & 0.98 \\
\hline & Plantago lanceolata & 93.0 & 0.43 & 110.5 & 0.95 & 77.0 & 0.23 \\
\hline & Poaceae & 93.5 & 0.44 & 105.0 & 0.77 & 105.5 & 0.66 \\
\hline & Polygonum aviculare & 105.0 & 0.77 & - & - & 109.5 & 0.91 \\
\hline & Polygonum bistorta & 93.5 & 0.44 & 106.0 & 0.80 & 103.5 & 0.72 \\
\hline & Populus sp. & 105.0 & 0.77 & - & - & 111.5 & 0.98 \\
\hline & Prunella vulgaris & 108.0 & 0.86 & 111.5 & 0.93 & - & - \\
\hline & Ranunculus acer & 106.0 & 0.80 & 102.0 & 0.67 & - & - \\
\hline & Rumex acetosa & 108.5 & 0.88 & 99.0 & 0.58 & 101.0 & 0.64 \\
\hline & Salix sp. & 105.0 & 0.77 & 99.0 & 0.56 & 110.5 & 0.95 \\
\hline & Taraxacum sp. & 105.5 & 0.78 & 112.5 & 1.00 & - & - \\
\hline & Trifolium pretense & 112.0 & 0.94 & 97.5 & 0.54 & - & - \\
\hline & Urtica dioica & 112.5 & 0.97 & 105.5 & 0.78 & 112.0 & 0.97 \\
\hline & Valeriana officinalis & 100.5 & 0.63 & 87.0 & 0.29 & 90.5 & 0.37 \\
\hline & Veronica sp. & 110.5 & 0.93 & - & - & - & - \\
\hline & Vicia cracca & 108.0 & 0.86 & - & - & - & - \\
\hline & Viola sp. & 110.0 & 0.93 & & 0.99 & 112.0 & 0.95 \\
\hline
\end{tabular}

The statistically significant values of probability level $(P)$ are in bold. 
and present greater light availability for much longer than narrow linear openings, where recolonization through the lateral spread of adjacent plants takes place very rapidly. Moreover, lesser light availability at the soil surface of linear gaps may be due to the absorption of solar radiation by the dense leaf canopy of plants growing at the opposing edges of openings. According to Anten and Hirose [39], efficient capture of light in meadows can be accomplished by both short- and tall-growing plants. The obtained results, showing that a shorter period of insolation in linear gaps contributes to increases in humidity within the gaps, correspond with the findings from studies carried out in croplands. Todd et al. [40] discovered that standing vegetation prevents water evaporation, while Teasdale and Mohler [41] documented that established vegetation prevents soil water loss and contributes to reductions in ground temperature.

\section{Number of species and seedlings in differently shaped gaps}

Contrary to expectations, the performed studies showed that in all the patches the number of species and seedling abundance were similar in differently shaped gaps. This phenomenon may be the result of the balanced effects of diverse environmental conditions in circular and linear openings.

The high level of light availability in circular openings may disrupt the dormancy of seeds of several taxa and trigger the germination process. Nevertheless, exposure to periods of drought before germination is complete might contribute to the suppression or delay of seedling development. Reductions in germination rates as a result of water deficit were observed repeatedly in several meadow taxa $[42,43]$. In linear gaps, contrastingly, the risk of drought-induced seed loss is much lower due to the vicinity of mature individuals which shade the openings and contribute to a decrease in water evaporation from the soil surface. Moreover, neighboring plants shelter diaspores from the activity of herbivores, playing the role of "nurse plants" [44]. On the other hand, the germination process and seedling development in linear gaps might be much slower than in circular openings due to insufficient light availability and nutrient depletion by adult plants surrounding the openings. The phenomenon of the suppression of germination and offspring growth as a result of the uptake of resources by mature plants has been shown repeatedly over a wide range of taxa from annual weeds [45], through grassland and meadow perennials [46-48], to shrubs and trees [49].

The performed investigations, showing equal recruitment in circular and linear gaps, are in accordance with the studies of Kotanen [50] who discovered that the total numbers of seedlings in differently shaped gaps created artificially in grassland do not vary.

\section{Recruitment rates of particular species in differently shaped gaps}

As a result of combining the performed studies with published data (Appendix S1), it can be asserted that the colonizers of circular gaps represent various vegetation types and diverse life forms. This phenomenon may be due to the vicinity of other plant communities such as calcareous grasslands, woodlots, and old fields. The obtained results, documenting that seedlings of Filipendula ulmaria, Geum rivale, Solidago canadensis and Iris sibirica appear mainly in round openings, are consistent with other studies [51-56] documenting that the absence of plants in the near vicinity and little competitive pressure from established vegetation may accelerate the recruitment process of these species. The observed greater recruitment of seedlings of Galinsoga sp. in circular gaps with considerable light intensity corresponds to the findings of other authors [56-58] who documented that seeds of Galinsoga ciliata and G. parviflora are positively photoblastic. Additionally, the substantial recruitment of Cirsium arvense, Tussilago farfara, Chenopodium album, Lysimachia vulgaris, Betula pendula and Sonchus arvensis in round gaps might be due to partial or absolute requirements of light for initiating and completing the germination process [59].

Analysis of the data showed that the colonizers of linear gaps are represented by meadow and grassland hemicryptophytes (Appendix S1). The results, showing that the offspring of Sanguisorba officinalis and Betonica officinalis appear more abundantly in linear gaps, support the observations of Lepš [60], who argued that they might recruit in the surroundings of neighboring plants. On the other hand, contrary to the obtained results, a number of scholars claim that the near vicinity of established vegetation has a negative impact on the density of seedlings of Lychnis flos-cuculi [61], Potentilla erecta [60], Succcisa pratensis [62], Serratula tinctoria [63], and Selinum carvifolia [22,60]. Additionally, Fitter and Peat [59] documented that a high level of light availability is necessary to initiate the germination processes of Serratula tinctoria and Selinum carvifolia.

The obtained results showed that the majority of species recruit in circular and linear openings similarly. This group of colonizers is represented by meadow hemicryptophytes in particular; however, phanerophytes and ruderals may also exhibit the same pattern of seedling recruitment (Appendix S1). The obtained findings correspond with the investigations of Gagnon et al. [64] who found similar seedling recruitment in differently shaped gaps in the tree species Pinus palustris.

\section{Implications for meadow conservation}

The formation of linear openings yields satisfactory results, enabling considerable recruitment of meadow hemicryptophytes. On the other hand, the creation of round openings, which affords opportunities for abundant recruitment of taxa representing various vegetation types and presenting different life forms, surprisingly may bring about a negative effect, contributing to the promotion of the secondary succession process. The recruitment of offspring of the phanerophyte Betula pendula and tall-growing ruderal hemicryptophyte Solidago canadensis, both characteristics of young tree communities, might contribute to the promotion of secondary succession. The invasive species Solidago canadensis, classified as the most widespread alien plant species in Europe [65], may contribute to the overgrowing of Molinietum caeruleae patches and the elimination of several native plants. Additionally, other authors have claimed that encroachment by Solidago canadensis may also eliminate other organisms such as ants [66], wild bees, hoverflies and butterflies [67] as well as birds [68]. 


\section{Acknowledgments}

I wish to thank two anonymous reviewers for helpful comments and valuable suggestions on earlier version of this paper. The study was conducted at author's own expense.

\section{Competing interests}

No competing interests have been declared.

\section{Supplementary material}

The following supplementary material for this article is available online at http://pbsociety.org.pl/journals/index.php/aa/rt/suppFiles/aa.2015.021/0: 1. Appendix S1: the seed germination requirements.

\section{References}

1. Falińska K. Alternative pathways od succession: species turnover patterns in meadows abandoned for 30 years. Phytocoenosis (N.S.). Arch Geobot. 2003;9:1-100.

2. Michalska-Hejduk D. Zmiany w składzie gatunkowym łąk trzęślicowych Molinietum caeruleae Kampinoskiego Parku Narodowego w latach 1994-2004. Studia Naturae. 2006;54(1):159-172.

3. Vandewalle M, Purschke O, de Bello F, Reitalu T, Prentice HC, Lavorel $\mathrm{S}$, et al. Functional responses of plant communities to management, landscape and historical factors in semi-natural grasslands. J Veg Sci. 2013;25(3):750-759. http://dx.doi.org/10.1111/jvs.12126

4. Kulik M. Changes of biodiversity and species composition of Molinia meadow depending on use method. Pol J Environ Stud. 2014;23(3):773-772.

5. Zarzycki K. O zachowanie wilgotnych łąk w Dolinie Górnej Wisły. Chrońmy Przyr Ojcz. 1956;12:11-17.

6. Tumidajowicz D, Zubel E. Zanikanie i przemiany łąk trzęślicowych (Molinietum coeruleae) w dolinie Wisły koło Czernichowa (Polska południowa). Fragm Flor Geobot. 1978;24:643-650.

7. Denisiuk Z. O ochronę nadwiślańskich łąk w Krakowie. Chrońmy Przyr Ojcz. 1987;43:22-31.

8. Gonzalez E, Hamrick JL. Distribution of genetic diversity among disjunct populations of the rare forest understory herb, Trillium reliquum. Heredity. 2005;95(4):306-314. http://dx.doi.org/10.1038/ sj.hdy.6800719

9. Honnay O, Jacquemyn H. Susceptibility of common and rare plant species to the genetic consequences of habitat fragmentation. Conserv Biol. 2007;21(3):823-831. http://dx.doi. org/10.1111/j.1523-1739.2006.00646.x

10. Kostrakiewicz K, Wróblewska A. Low genetic variation in subpopulations of an endangered clonal plant Iris sibirica in southern Poland. Ann Bot Fenn. 2008;45:186-194. http://dx.doi.org/10.5735/085.045.0303

11. Morgan JW, Meyer M, Young AG. Severe habitat fragmentation leads to declines in genetic variation, mate availability, and reproductive success in small populations of a once-common Australian grassland daisy. Int J Plant Sci. 2013;174(9):1209-1218. http://dx.doi.org/10.1086/673242

12. Czarnecka B, Denisow B. Floral biology of Senecio macrophyllus M. BIEB. (Asteraceae), a rare Central European steppe plant. Acta Soc Bot Pol. 2014;83(1):29-37. http://dx.doi.org/10.5586/asbp.2014.002

13. Prévosto B, Kuiters L, Bernhardt-Romermann M, Dolle M, Schmidt W, Hoffmann M, et al. Impacts of land abandonment on vegetation: successional pathways in European Habitats. Folia Geobot. 2011;46(4):303-325. http://dx.doi.org/10.1007/s12224-010-9096-Z

14. Denisiuk Z. Interaction between agriculture and nature conservation in Poland. Gland: Switzerland ICUN Press and Cambridge University Press; 1991.

15. Fuller RM. The changing extent and conservation interest of lowland grasslands in England and Wales: a review of grassland surveys 1930-84. Biol Conserv. 1987;40:281-300. http://dx.doi. org/10.1016/0006-3207(87)90121-2

16. Green BH. Agricultural intensification and loss of habitat, species and amenity in British grasslands: review of historical change and assessment of future prospects. Grass and Forage Science. 1990;45:365372. http://dx.doi.org/10.1111/j.1365-2494.1990.tb01961.x

17. Prach K. Vegetational changes in a wet meadow complex, South Bohemia, Czech Republic. Folia Geobotanica and Phytotaxonomica. 1993;28:1-13.

18. Muller S. Diversity and management practice required to ensure conservation of rare and locally threatened species in grassland: a case studies at regional scale (Lorraine, France). Biodivers Conserv. 2000;11:1173-1184. http://dx.doi.org/10.1023/A:1016049605021

19. Council Directive 92/43/EEC of 21 May 1992 on the conservation of natural habitats and of wild fauna and flora. OJ L. 1992;206:7-50.

20. Council Directive 97/62/EC of 27 October 1997 adapting to technical and scientific progress Directive 92/43/EEC on the conservation of natural habitats and of wild fauna and flora. OJ L. 1997;305:42-65.

21. Interpretation manual of European Union habitats [Internet]. 2007 [cited 2015 Jun 19]; Available from http://ec.europa.eu/environment/ nature/legislation/habitatsdirective/docs/2007_07_im.pdf

22. Špačkova I, Kotorová I, Lepš J. Sensivity of seedling recruitment to moss, litter and dominant removal in an oligotrophic wet meadow. Folia Geobot. 1998;33:17-30. http://dx.doi.org/10.1007/BF02914928

23. Kotorová I, Lepš J. Comparative ecology of seedling recruitment in an oligotrophic wet meadow. J Veg Sci. 1999;10:175-186. http://dx.doi. org/10.2307/3237139

24. Špačkova I, Lepš J. Variability of seedling recruitment under dominant, moss and litter removal over four years. Folia Geobot. 2004;29:41-55. http://dx.doi.org/10.1007/BF02803263

25. Janeček S, Lepš J. Effect of litter, leaf cover and cover of basal internodes of the dominant species Molinia caerulea on seedling recruitment and established vegetation. Acta Oecol (Montrouge). 2005;28(2):141-147. http://dx.doi.org/10.1016/j.actao.2005.03.006

26. Fibich P., Vitová A, Macek P., Lepš J, Cáceres M. Establishment and spatial associations of recruits in meadow gaps. J Veg Sci. 2013;24:496505. http://dx.doi.org/10.1111/j.1654-1103.2012.01486.x

27. Kostrakiewicz K. The effect of gap size on colonization process in Molinietum caeruleae meadows with different habitat conditions. Pol J Ecol. 2011;59:677-686.

28. Kostrakiewicz-Gierałt K. The impact of neighbourhood and gap character on seedling recruitment of Trollius europaeus L. and Iris sibirica L. in Molinietum caeruleae meadows. Biodiv Res Conserv. 2012;28:37-44. http://dx.doi.org/10.2478/v10119-012-0026-1

29. Kostrakiewicz-Gierałt K. The impact of disturbance gradient on recruitment of clonal plant species in Molinietum caeruleae meadows. Pol J Ecol. 2013;61:519-533.

30. Kostrakiewicz-Gierałt K. The effect of successional stage and size of gaps on recruitment of clonal plants in overgrowing Molinietum caeruleae meadows. Acta Agrobot. 2014;67(4):87-98. http://dx.doi. org/10.5586/aa.2014.044

31. Dubiel E. Mapa zbiorowisk roślinnych III Kampusu Uniwersytetu Jagiellońskiego i okolic. Kraków: Instytut Botaniki UJ; 2005.

32. Dubiel E. Mapa roślinności aktualnej Krakowa. Zesz Nauk UJ Prace Bot. 1991;22:121-133.

33. Dubiel E. Łąki Krakowa. I Klasa Molinio-Arrhenatheretea. Studia Ośr Dok Fizjogr PAN. 1996;24:145-171.

34. Matuszkiewicz W. Przewodnik do oznaczania zbiorowisk roślinnych Polski. Warszawa: Wydawnictwo Naukowe PWN; 2001.

35. Csapodý V. Keimlingsbestimmungsbuch der Dikotyledonen. Budapest: Akademiai Kiado; 1968.

36. Muller FM. Seedlings of the North-western European lowland. A flora of seedlings. The Hague: Dr. W. Junk B.V. Publisher and Centre for Agricultural Publishing and Documentation; 1978. http://dx.doi. org/10.1007/978-94-009-9981-7

37. Mirek Z, Piękoś-Mirkowa H, Zając A, Zając M. Flowering plants and pteridophytes of Poland - a checklist. Kraków: W. Szafer Institute of Botany, Polish Academy of Sciences; 2002. (Biodiversity of Poland; vol 1) 
38. Sousa WP. The role of disturbance in natural communities. Annu Rev Ecol Syst. 1984;15:353-391. http://dx.doi.org/10.1146/annurev. es.15.110184.002033

39. Anten NPR, Hirose T. Interspecific differences in above-ground growth patterns result in spatial and temporal partitioning of light among species in a tall-grass meadow. J Ecol. 1999;87(4):583-597. http://dx.doi.org/10.1046/j.1365-2745.1999.00365.x

40. Todd RW, Klocke NL, Hergert GW, Parkhurst AM. Evaporation from soil influenced by crop shading, crop residue and wetting regime. Trans ASAE. 1991;34:2:461-466. http://dx.doi.org/10.13031/2013.31684

41. Teasdale JR, Mohler CL. Light transmittance, soil temperature, and soil moisture under residue of hairy vetch and rye. Journal of Agronomy. 1993;85(3):673-680. http://dx.doi.org/10.2134/agronj1993.00021962 $008500030029 x$

42. Evans CE, Etherington JR. The effect of soil water potential on seed germination of some British plants. New Phytol. 1990;115:539-548. http://dx.doi.org/10.1111/j.1469-8137.1990.tb00482.x

43. Pérez-Fernández MA, Calvo-Magro E, Ferrer-Castán D. Simulation of germination of pioneer species along an experimental drought gradient. J Environ Biol. 2006;27(4):669-685.

44. Ren H, Yang L, Liu N. Nurse plant theory and its application in ecological restoration in lower subtropics of China. Prog Nat Sci. 2008;18(2):137-142. http://dx.doi.org/10.1016/j.pnsc.2007.07.008

45. Taylorson RB, Borthwick HA. Light filtration by foliar canopies: significance for light-controlled weed seed germination. Weed Sci. 1969;17(1):48-51.

46. Silvertown J. Leaf-canopy-induced seed dormancy in a grassland flora. New Phyol. 1980;85:109-118. http://dx.doi. org/10.1111/j.1469-8137.1980.tb04452.x

47. Leishman MR. How well do plant traits correlate with establishment ability? Evidence from a study of 16 calcareous grassland species. New Phytol. 2002;141(3):487-496. http://dx.doi. org/10.1046/j.1469-8137.1999.00354.x

48. Forbis T. Negative associations between seedlings and adult plants in two alpine plant communities. Arct Antarct Alp Res. 2009;3(41):301308. http://dx.doi.org/10.1657/1938-4246-41.3.301

49. Grellier S, Barot S, Janeau JL, Ward D. Grass competition is more important than seed ingestion by livestock for Acacia recruitment in South Africa. Plant Ecol. 2012;213: 899-908. http://dx.doi.org/10.1007/ s11258-012-0051-3

50. Kotanen PM. Effect of gap area and shape on recolonization by grassland plants with differing reproductive strategies. Can J Bot. 1997;75:352-361. http://dx.doi.org/10.1139/b97-037

51. Falińska K, Lembicz M, Jarmolowski A, Borkowska L. Patterns of genetic diversity in populations of Filipendula ulmaria (L.) at different stages of succession on a meadow abandoned for 30 years. Pol J Ecol. 2010;58:27-40.

52. Kiviniemi K. Population dynamics of Agrimonia eupatoria and Geum rivale, two perennial grassland species. Plant Ecol. 2002;159:153-169. http://dx.doi.org/10.1023/A:1015506019670

53. Ruprecht E, Fenesi A, Nijsb I. Sudden changes in environmental conditions do not increase invasion risk in grassland. Acta Oecol (Montrouge). 2013;47:8-15. http://dx.doi.org/10.1016/j.actao.2012.11.003

54. Kostrakiewicz K. The effect of dominant species on numbers and age structure of Iris sibirica L. population on blue moor-grass meadow in southern Poland. Acta Soc Bot Pol. 2007;76:165-173. http://dx.doi. org/10.5586/asbp.2007.020

55. Kostrakiewicz K. Population structure of a clonal endangered plant species Iris sibirica L. in different habitat conditions. Pol J Ecol. 2008;56:581-592.

56. Ivany JA, Sweet RD. Germination, growth, development, and control of Galinsoga. Weed Sci. 1973;21:41-45.

57. Jursik M, Soukup J, Venclová V, Holec J. Seed dormancy and germination of Shaggy soldier (Galinsoga ciliata Blake.) and Common lambsquarter (Chenopodium album L.). Plant Soil Environ. 2003;49:511-518.
58. de Cauwer B, Devos R, Claerhout S, Bulcke R, Reheul D. Seed dormancy, germination, emergence and seed longevity in Galinsoga parviflora and G. quadriradiata. Weed Res. 2014;54:38-47. http:// dx.doi.org/10.1111/wre.12055

59. Fitter AH, Peat HJ. The Ecological Flora Database. J Ecol. 1994;82:415425. http://dx.doi.org/10.2307/2261309

60. Lepš J. Nutrient status, disturbance and competition: an experimental test of relationships in a wet meadow. J Veg Sci. 1999;10:219-230. http://dx.doi.org/10.2307/3237143

61. Rasran L, Vogt K, Jensen K. Effects of litter removal and mowing on germination and establishment of two fen-grassland species along a productivity gradient. Folia Geobot. 2007;42:271-288. http://dx.doi. org/10.1007/BF02806467

62. Isselstein J, Tallowin JRB, Smith REN. Factors affecting seed germination and seedling establishment of fen-meadow species. Restoration Ecology. 2002;10:173-184. http://dx.doi. org/10.1046/j.1526-100X.2002.00045.x

63. Bissels S, Hölzel N, Otte A. Population structure of the threatened perennial Serratula tinctoria in relation to vegetation and management. J Veg Sci. 2004;7:267-272. http://dx.doi. org/10.1658/1402-2001(2004)007[0267:PSOTTP]2.0.CO;2

64. Gagnon JL, Jokela EJ, Moser WK, Huber DA. Characteristics of gaps and natural regeneration in mature longleaf pine flatwoods ecosystems. For Ecol Manage. 2003;177:373-380. http://dx.doi.org/10.1016/ s0378-1127(03)00378-5

65. Lambdon PW, Pyšek P, Basnou C, Hejda M, Arianoutsou M, Essl F, et al. Alien flora of Europe: species diversity, temporal trends, geographical patterns and research needs. Preslia. 2008;80:101-149.

66. Lenda M, Witek M, Skórka P, Moroń D. Invasive alien plants affect grassland ant communities, colony size and foraging behavior. Biol Invasions. 2013;15(11):2403-2414. http://dx.doi.org/10.1007/ s10530-013-0461-8

67. Skórka P, Lenda M, Tryjanowski P. Invasive alien goldenrods negatively affect grassland bird communities in Eastern Europe. Biol Conserv. 2010;143:856-861. http://dx.doi.org/10.1016/j.biocon.2009.12.030

68. Moroń D, Lenda M, Skórka P, Szentgyorgyi H, Settele J, Woyciechowski M. Wild pollinator communities are negatively affected by invasion of alien goldenrods in grassland landscapes. Biol Conserv. 2009;142(7):1322-1332. http://dx.doi.org/10.1016/j. biocon.2008.12.036

\section{Wpływ kształtu luk na warunki mikrosiedliskowe i rekrutację siewek w płatach Molinietum caeruleae}

\section{Streszczenie}

Głównym celem prezentowanych badań było zbadanie wpływu kształtu luk na warunki mikrosiedliskowe i rekrutację siewek w płatach łąk Molinietum caeruleae. Obserwacje prowadzono w Krakowie-Kostrzu (Polska Poludniowa) w płatach zdominowanym przez niewielkie gatunki łąkowe (powierzchnia I), ziołorośla i wysokokepowe trawy (powierzchnia II) oraz krzewiaste gatunki wierzb (powierzchnia III). We wszystkich płatach okragłe i podłużne luki o podobnej powierzchni zostały utworzone przez usunięcie nadziemnych części roślin oraz warstwy ściółki. Okrągłe luki cechowała większa dostępność światła i niższa wilgotność gruntu niż podłużne, natomiast temperatura powierzchni gleby w obu rodzajach odsłonięć była podobna. Niezależnie od warunków siedliskowych całkowita liczba gatunków i siewek w lukach o odmiennym kształcie była zbliżona. W puli siewek stwierdzono gatunki występujące głównie w okrągłych lukach, gatunki pojawiające się przeważnie w prostokątnych lukach, jak również kolonizujące zarówno okrągłe, jak i prostokątne odsłonięcia. Do kolonizatorów okrągłych luk należały gatunki ruderalne, murawowe, łąkowe oraz leśne, reprezentujące różne formy życiowe (od terofitów, przez hemikryptofity i chamefity, do fanerofitów). Kolonizatorami podłużnych luk były łąkowe i murawowe hemikryptofity. W świetle przeprowadzonych badań można wnioskować, że tworzenie podłużnych luk przynosi pożądane efekty, natomiast tworzenie okrągłych odsłonięć może nieść negatywne skutki związane z przyspieszeniem procesu sukcesji wtórnej. 